\title{
Mesomorphism Molecular Rigidity and Flexibility
}

\author{
Y. B. Dudhagara, G. N. Bhola, U. C. Bhoya* \\ Department of Chemistry, Saurashtra University, Rajkot-360005, Gujarat, India. \\ E-mail address: yogeshdudhagar25292@gmail.com, bholagn@gmail.com, drucbhoya@gmail.com
}

Keywords: liquid crystal; smectic; nematic; mesomorphism, mesophase

\begin{abstract}
A novel homologous series of liquid crystalline (LC) behaviors of Schieff's bases: RO$\mathrm{C}_{6} \mathrm{H}_{4}-\mathrm{CH}=\mathrm{CH}-\mathrm{COO}-\mathrm{C}_{6} \mathrm{H}_{4}-\mathrm{N}=\mathrm{CH}-\mathrm{C}_{6} \mathrm{H}_{4}-\mathrm{OC}_{2} \mathrm{H}_{5}$ have been synthesized and studied with a view to understand and establish the effect of molecular structure on LC properties of a novel substances. The members of a novel series are enantiotropically nematogenic $\left(\mathrm{C}_{1}\right.$ to $\left.\mathrm{C}_{10}\right)$ or the some of the homologues $\left(\mathrm{C}_{12}\right.$ to $\left.\mathrm{C}_{18}\right)$ are smectogenic phase nematogenic. Transition temperatures, textures and melting behaviors observed or determined by an optical polarizing microscopy equipped with a heating stage. Thermometric temperatures are varied between $102{ }^{\circ} \mathrm{C}$ and $311{ }^{\circ} \mathrm{C}$. Textures of the nematic phases are threaded or schlieren and that of the smectic phases are of the type A or C. Smectic and nematic thermal stabilities are $122.5^{\circ} \mathrm{C}$ and $270.7{ }^{\circ} \mathrm{C}$. Total mesophase lengths vary from $111.0{ }^{0} \mathrm{C}$ to $194.0{ }^{\circ} \mathrm{C}$. Analytical and spectral data confirms the molecular structures of homologues. Some LC properties o present novel series are compared with the structurally similar known series. Transition curves viz. $\mathrm{Cr}-\mathrm{M}, \mathrm{Sm}-\mathrm{N}$ and N-I behaved in normal manner. N-I transition curve exhibited odd-even effect. Thus present novel series is partly smectogenic and fully nematogenic with high mesophase length and higher observed melting type.
\end{abstract}

\section{INTRODUCTION}

Scientist and technologists working on liquid crystalline state[1] of a substance with different aims, objects and views in the interest of mankind. The LCD products have to avail at an economical cost $[2,3,4,5,6$,$] . Therefore irrespective of their type of aims, objects, views and$ goals, or research scientist or technologist always need the novel LC substances for their continuation of research. Therefore present investigation is planned with a view to understand and establish the effect of molecular structure on LC properties [7, 8, 9, 10,] by synthesizing novel LC substances through unexploited moieties. Thus, study will include the availability of novel alternative LC substances to the researchers working in application part. The novel substances will be characterized and then reported with evaluation of thermometric data and will be interpreted and compared with structurally similar series on the basis of molecular rigidity and flexibility [11, 12, 13, 14,]. Number of homologous series have been reported till the date $[15,16,17,18,19,20,21$, 22 ,] but present series will consist of three phenyl rings bonded through $-\mathrm{CH}=\mathrm{CH}-\mathrm{COO}-$ and $\mathrm{N}=\mathrm{CH}$ - central bridges as well as left and right $-\mathrm{OR}$ and $-\mathrm{OC}_{2} \mathrm{H}_{5}$ end groups.

\section{EXPERIMENTAL}

\section{Synthesis}

4-n-Alkoxybenzaldehydes were synthesized by refluxing 4-hydroxybenzaldehyde (1 equiv.) with corresponding $\mathrm{n}$-alkyl bromides ( 1 equiv.) in the presence of potassium carbonate (1 equiv.) and acetone as a solvent [23]. The resulting 4-n-alkoxybenzaldehydes were reacted with malonic acid (1.2 equiv.) in the presence of 1-2 drops piperidine as catalyst and pyridine as solvent to yield corresponding trans 4-n-alkoxy cinnamic acids (A) [24]. (E)-4-((4-ethoxybenylidene) amino) phenol (B) was prepared by an established method [25] M.P. $196^{\circ} \mathrm{C}$, Yield- $69.2 \%$. Coupling of compound $\mathrm{A}$ and compound $\mathrm{B}$ is done by steglichesterification to yield $\mathrm{p}$-(p'-n-alkoxy cinnamoyloxy)-(p"-ethoxy benzylidene) aniline [26]. 
The synthesis route to the novel homologous series is under mentioned in scheme-1.

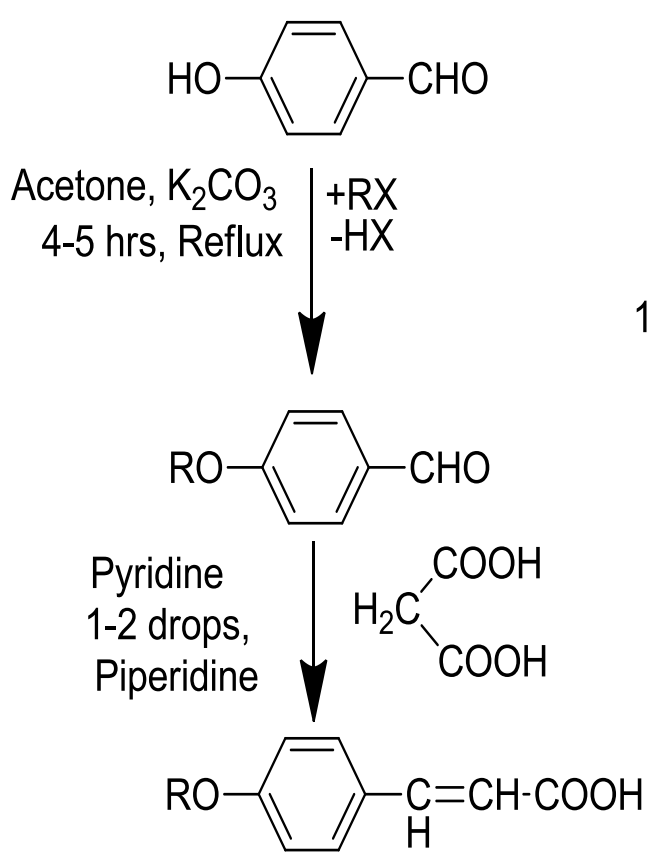

$[\mathrm{A}]$

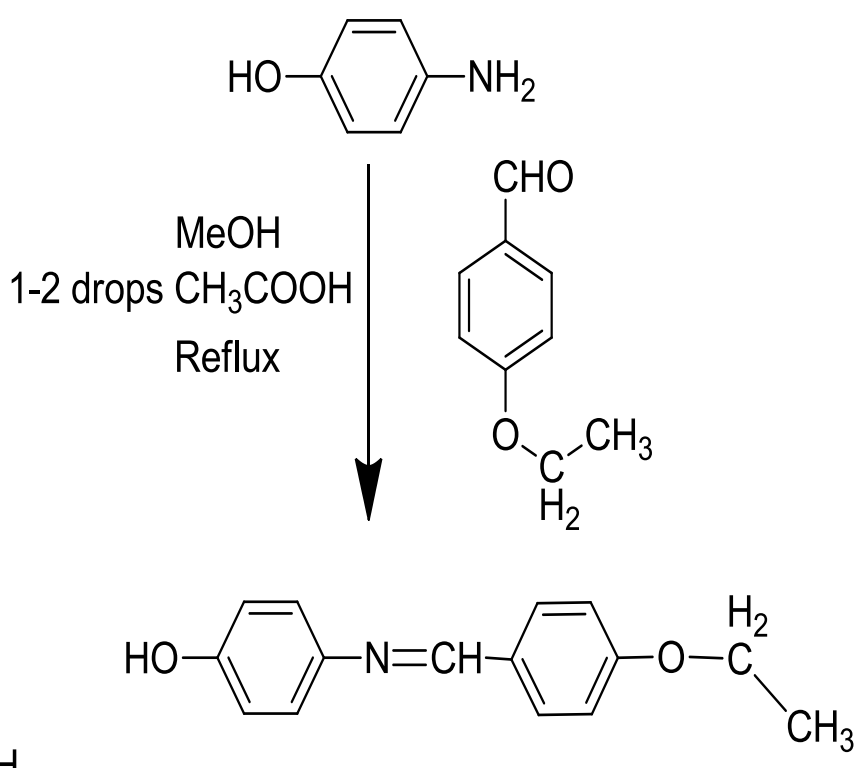

[B]

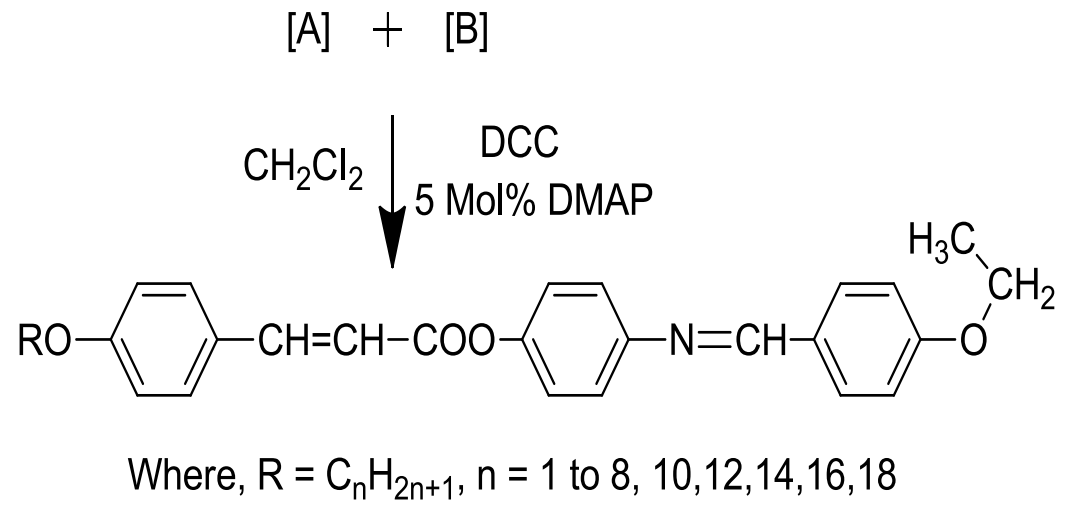

Scheme 1: Synthesis route to the novel homologous series

\section{CHARACTERIZATION}

Some of members of a novel series as the representative member of a series were characterized by elemental analysis (Table-1), Infrared spectroscopy, ${ }^{1} \mathrm{H}$ NMR spectra and mass spectroscopy. Microanalysis was performed on EuroEA Elemental Analyzer. IR spectra were recorded on Shimadzu FTIR Model-IRAffinity-1S (MIRacle 10), ${ }^{1} \mathrm{H}$ NMR spectra were recorded on Bruker spectrometer using $\mathrm{CDCl}_{3}$ as a solvent and mass spectra were recorded on Shimadzu GCMS Model No.QP-2010. 


\section{Analytical data}

Table 1: Elemental analysis for (1) Dodecyloxy (2) Tetradecyloxy (3) Octadecyloxy derivatives

\begin{tabular}{|c|c|c|c|c|c|c|c|c|c|}
\hline \multirow{2}{*}{$\begin{array}{l}\text { Sr. } \\
\text { No. }\end{array}$} & \multirow{2}{*}{$\begin{array}{l}\text { Molecular } \\
\text { formula }\end{array}$} & \multicolumn{4}{|c|}{ Elements \%Found } & \multicolumn{4}{|c|}{ Elements \%Calculated } \\
\hline & & $\mathrm{C}$ & $\mathrm{H}$ & $\mathrm{O}$ & $\mathrm{N}$ & $\mathrm{C}$ & $\mathrm{H}$ & $\mathrm{O}$ & $\mathrm{N}$ \\
\hline 1 & $\mathrm{C}_{36} \mathrm{H}_{45} \mathrm{NO}_{4}$ & 77.75 & 8.35 & 11.50 & 2.49 & 77.80 & 8.16 & 11.52 & 2.52 \\
\hline 2 & $\mathrm{C}_{38} \mathrm{H}_{49} \mathrm{NO}_{4}$ & 78.10 & 8.35 & 10.45 & 2.36 & 78.18 & 8.46 & 10.96 & 2.40 \\
\hline 3 & $\mathrm{C}_{42} \mathrm{H}_{57} \mathrm{NO}_{4}$ & 78.59 & 8.95 & 10.00 & 2.14 & 78.63 & 8.98 & 10.00 & 2.19 \\
\hline
\end{tabular}

\section{Spectral Data:}

${ }^{1}$ H NMR in ppm for Propyloxy Derivative

$1.05\left(\mathrm{t}, 3.68 \mathrm{H},-\mathrm{CH}_{3}\right.$ of $-\mathrm{CH}_{2}-\mathrm{CH}_{3}$ group), 1.45 (t, 3.26H,- $-\mathrm{CH}_{2}-\mathrm{CH}_{3} 1.85$ (Sextet $3.26 \mathrm{H},-\mathrm{CH}_{2}-\mathrm{CH}_{2}-$ $\left.\mathrm{CH}_{3}\right), 3.95$ (t, $\left.2.44 \mathrm{H},-\mathrm{O}-\mathrm{CH}_{2} \mathrm{CH}_{2}-\right), 4.10$ (q, 2.29H, - $\left.-\mathrm{CH}_{2} \mathrm{CH}_{3}\right), 6.50$ (d, $\left.1.02 \mathrm{H},-\mathrm{CH}=\mathrm{CH}-\right), 6.90$ (q, $4.13 \mathrm{H}$, middle phenyl ring), $7.2(4.59 \mathrm{H}$, phenyl ring with ethoxy chain), $7.5 \& 7.85(5 \mathrm{H}$, phenyl ring with alkoxy chain), $8.4(\mathrm{~s}, 1.00 \mathrm{H},-\mathrm{N}=\mathrm{CH}-)$ The $\mathrm{NMR}$ data are reliable with the molecular structure.

\section{${ }^{1}$ HNMR in ppm for Hexyloxy Derivative}

0.90 (t, 3.05H, $-\mathrm{CH}_{3}$ of- $-\mathrm{CH}_{2}-\mathrm{CH}_{2}-\mathrm{CH}_{3}$ group), 1.20 (m, 4.23, $-\mathrm{CH}_{2}-\mathrm{CH}_{2}-\mathrm{CH}_{2}-1.3$ (m, 5.04H, $\mathrm{CH}_{2}-$ $\left.\mathrm{CH}_{2}-\mathrm{CH}_{2}\right), 1.8\left(\mathrm{p}, 2.0 \mathrm{H},-\mathrm{CH}_{2}-\mathrm{CH}_{2}-\mathrm{CH}_{2}-\right), 4.00$ (t, $\left.2.03 \mathrm{H},-\mathrm{O}-\mathrm{CH}_{2} \mathrm{CH}_{2}-\right), 4.10$ (q, 2.29H, , -O$\left.\mathrm{CH}_{2} \mathrm{CH}_{3}\right), 6.50(\mathrm{~d}, 1.02 \mathrm{H},-\mathrm{CH}=\mathrm{CH}-) 6.90(\mathrm{q}, 4.13 \mathrm{H}$, middle phenyl ring), $7.2(4.59 \mathrm{H}$, phenyl ring with ethoxy chain), $7.5 \& 7.85(5 \mathrm{H}$, phenyl ring with alkoxy chain), $8.4(\mathrm{~s}, 1.00 \mathrm{H},-\mathrm{N}=\mathrm{CH}-)$ The NMR data are reliable with the molecular structure.

\section{IR in $\mathbf{c m}^{-1}$ for Decyloxy Derivative}

2924.09 (C-H str. of alkan), $2854.65\left(\mathrm{C}-\mathrm{H}\right.$ str. of $\left(-\mathrm{CH}_{2}-\right)_{\mathrm{n}}$ group of $\left.-\mathrm{OC}_{10} \mathrm{H}_{21}\right), 1712.79(\mathrm{C}=\mathrm{O}$ str. of carbonyl carbon of ester group), $1627(\mathrm{C}=\mathrm{O}$ str. of $\alpha, \beta$ unsaturated ketone $), 1604.77(\mathrm{C}=\mathrm{C}$ str. of alkene), 1473.62, 1504.48 and $1573.91(\mathrm{C}=\mathrm{C}$ str. of aromatic ring), 995.27 ( $\mathrm{C}-\mathrm{H}$ bending of alkene disubstituted), 1165.00 (C-O str. of ether linkage), 1242.16 (C-O str. of ester group), 1388.75 (C-H bending of alkene). The IR data are consistent with the molecular structure.

\section{IR in $\mathbf{~ c m}^{-1}$ for butyloxy Derivative}

$2954.95\left(\mathrm{C}-\mathrm{H}\right.$ str. of alkane), $2870.08\left(\mathrm{C}-\mathrm{H}\right.$ str. of $\left(-\mathrm{CH}_{2}-\right)_{\mathrm{n}}$ group of $\left.-\mathrm{OC}_{4} \mathrm{H}_{9}\right), 1728.22(\mathrm{C}=\mathrm{O}$ str. of carbonyl carbon of ester group), $1627(\mathrm{C}=\mathrm{O}$ str. of $\alpha, \beta$ unsaturated ketone $), 1604.77(\mathrm{C}=\mathrm{C}$ str. of alkene), 1473.62, 1504.48, and $1566.20(\mathrm{C}=\mathrm{C}$ str. of aromatic ring), $972.12(\mathrm{C}-\mathrm{H}$ bending of alkene disubstituted), 1165.00 (C-O str. of ether linkage), 1249.87 (C-O str. of ester group), 1388.75 (C-H bending of alkane). The IR data are consistent with the molecular structure.

\section{Mass spectra of Ethyloxy Derivative}

m/z (rel.int\%): $415(\mathrm{M})^{+}, 240,212,183,175,147,119,91,65$

\section{Mass spectra of Heptyloxy Derivative}

m/z (rel.int\%): $485(\mathrm{M})^{+}, 245,212,, 183,147,119,91,77,57$, 


\section{RESULTS AND DISCUSSION}

4-Hydroxy derivatives of a Schiff's base is a liner lath like molecule is a nonmesomorphic (m.p.202 yield $80 \%$ ) but on linking it with trans 4-n-alkoxy cinnamic acids yielded mesomorphic derivatives of ester, with high transition temperatures high degree of mesomorphism. $\mathrm{C}_{1}$ to $\mathrm{C}_{18}$ homologues are nematogenic but $\mathrm{C}_{12}$ to $\mathrm{C}_{18}$ includes smectogenic character in addition to nematic property. Transition temperatures (table-2) as determined from an optical polarizing microscopy equipped with a heating stage are potted against the number of carbon atoms present in n-alkyl chain bonded to first phenyl ring through oxygen atom. A phase diagram (figure-1) is obtained showing phase behaviors of series through Cr-M, Sm-N and N-I transition curves formed by linking like or related points. A Cr-M transition curve follows a zigzag path of rising and falling with overall descending tendency as series is ascended and behaved in normal established manner. A $\mathrm{Sm}-\mathrm{N}$ transition curve initially raises form $\mathrm{C}_{12}$ and continued to rise up to $\mathrm{C}_{18}$ without exhibition of odd-even effect. It extrapolated $[27,28,29,30]$ to $\mathrm{C}_{10}$ homologue to determine its ability to exhibit smectic properties. Extrapolated curve merges to $\mathrm{Cr}-\mathrm{M}$ point which suggests the inability of $\mathrm{C}_{10}$ to form smectic phase. Thus, it behaved in normal manner. An N-I transition curve continuously descended as series is ascended with overall descending tendency and exhibition of odd- even effect. Thus, it behaved in normal expected manner. The textures of nematic phase are threaded or schlieren and that of smectic phase are fan shape or batonates of the type A or smectic-C. The analytical and spectral data confirmed the molecule structures of novel homologues. Thus, a novel homologous series is partly smectogenic and fully nematogenic whose, mesogenic phase length vary form $111^{\circ} \mathrm{C}$ to $194{ }^{\circ} \mathrm{C}$ and high ordered melting type.

Table 2: Transition temperatures in ${ }^{\circ} \mathrm{C}$

\begin{tabular}{|c|c|c|c|c|}
\hline $\begin{array}{c}\text { Compound } \\
\text { No. }\end{array}$ & $\begin{array}{c}\text { n-alkyl chain } \\
\mathbf{C}_{\mathbf{n}} \mathbf{H}_{\mathbf{2 n + 1}}(\mathbf{n})\end{array}$ & Smectic & Nematic & Isotropic \\
\hline 1 & $\mathrm{C}_{1}$ & - & 159 & 307 \\
\hline 2 & $\mathrm{C}_{2}$ & - & 164 & 311 \\
\hline 3 & $\mathrm{C}_{3}$ & - & 147 & 295 \\
\hline 4 & $\mathrm{C}_{4}$ & - & 138 & 301 \\
\hline 5 & $\mathrm{C}_{5}$ & - & 140 & 290 \\
\hline 6 & $\mathrm{C}_{6}$ & - & 118 & 290 \\
\hline 7 & $\mathrm{C}_{7}$ & - & 128 & 282 \\
\hline 8 & $\mathrm{C}_{8}$ & - & 125 & 271 \\
\hline 9 & $\mathrm{C}_{10}$ & - & 106 & 256 \\
\hline 10 & $\mathrm{C}_{12}$ & 102 & 109 & 238 \\
\hline 11 & $\mathrm{C}_{14}$ & 110 & 115 & 232 \\
\hline 12 & $\mathrm{C}_{16}$ & 107 & 131 & 227 \\
\hline 13 & $\mathrm{C}_{118}$ & 109 & 135 & 220 \\
\hline
\end{tabular}




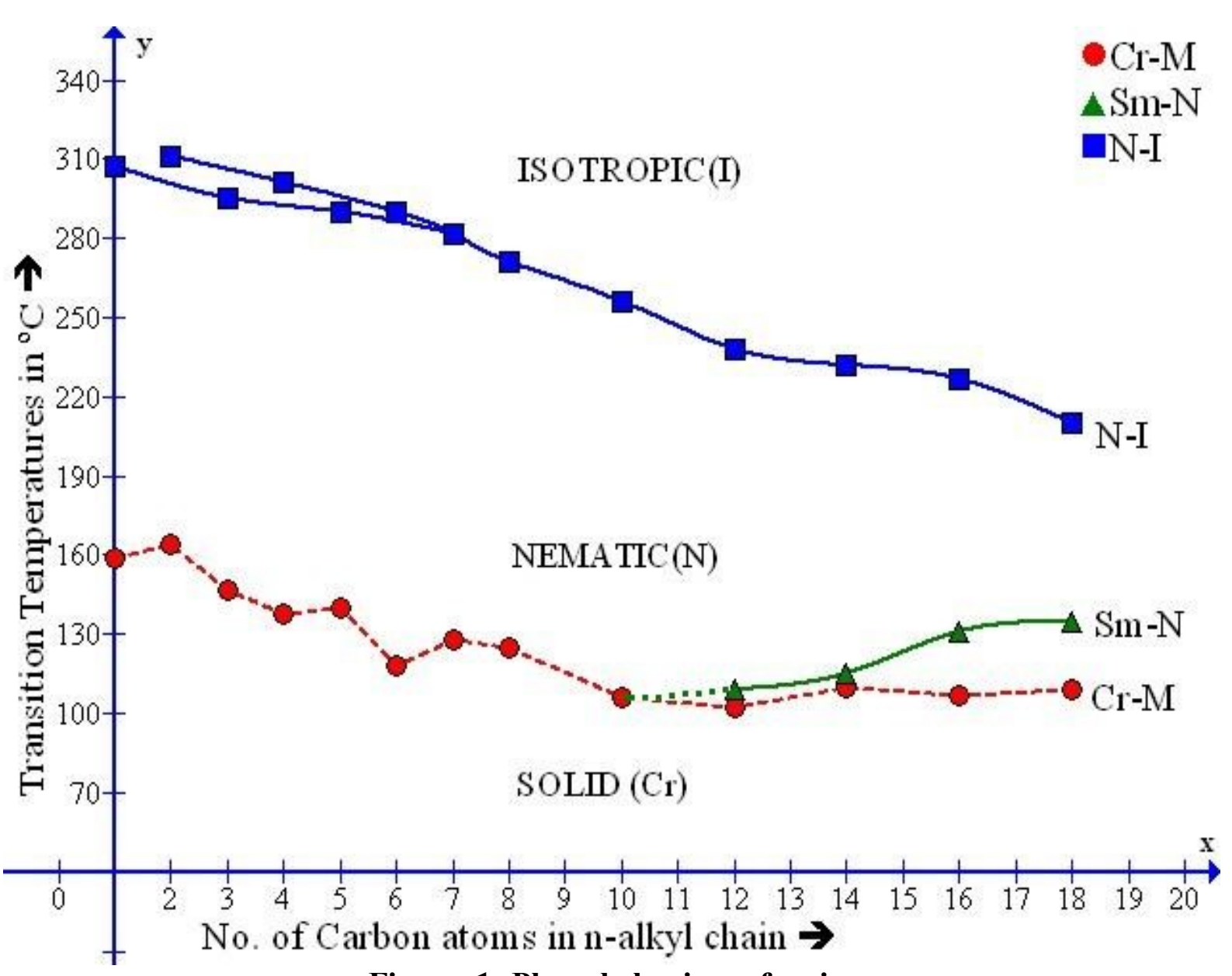

Figure 1: Phase behaviors of series

The N-I transition curve for odd and even members merge into each other at the $\mathrm{C}_{7}$ member of a series and then odd-even effect disappears from and beyond $\mathrm{C}_{7}$ for higher homologues for which single transition curve prolongs. N-I transition curves for odd member's occupied lower position as compared to a curve for even member.

High transition temperatures and high degree of mesomorphism is attributed to the three phenyl rings and their linking through $-\mathrm{CH}=\mathrm{CH}-\mathrm{COO}$ - and $-\mathrm{N}=\mathrm{CH}$ - central bridges bearing conjugated double bonds which increases molecular rigidity, to a considerable extent. Moreover, the highly polar common $-\mathrm{OC}_{2} \mathrm{H}_{5}$ tail end group and left changing - OR group increases molecular flexibility and consequently end to end intermolecular dispersion forces are also enhanced, which induces nematogenic character through out the novel series under discussion. As molecular size is progressively raised, the strengthening of intermolecular forces of attractions is favorable to build up lamellar packing of molecules form and beyond $\mathrm{C}_{12}$ homologue to induce smectogenic character in addition to nematogenic character. The late commencement of a smectic phase from $\mathrm{C}_{12}$ homologue is attributed to the extent of molecular noncoplanarity which arises from changing -OR terminal end group which properly first to the extent of noncoplanarity of molecule. The appearance of odd-even effect is attributed to the sequential addition of methylene unit or units to the left nalkoxy terminal end group. The disappearance of add and even effect from and beyond $\mathrm{C}_{7}$ homologue is attributed to the coiling, bending, flexing or coupling of the longer n-alkyl chain with the principle axes of a core structure of a molecule. Alternation of transition temperatures are due to odd and even number of carbon atoms in n-alkyl chain of the left n-alkoxy terminal end group. Changing trend in number of methylene unit causes variations in mesomorphic properties from homologue to homologue in the same series. The mesomorphic properties of presently investigated novel series are compared with known homologous series as shown in figure-2. 


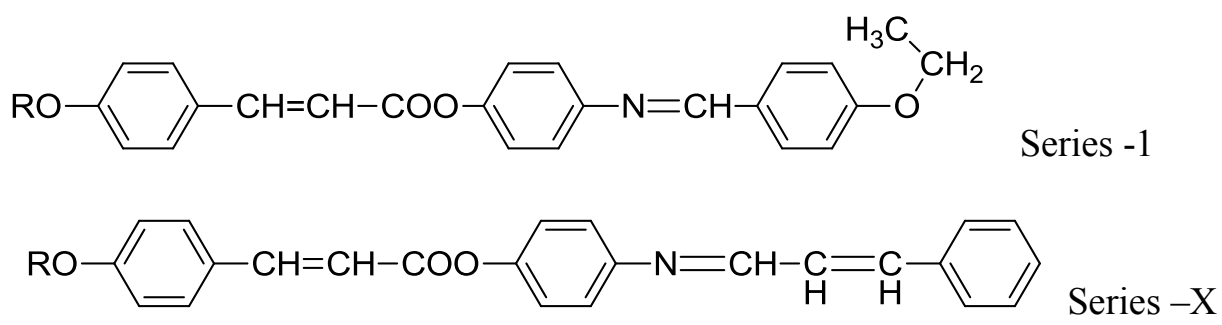

Figure 2: Structurally similar series

Homologous series 1 and $\mathrm{X}$ [31] are identical with respect to three phenyl rings, central bridge $-\mathrm{CH}=\mathrm{CH}-\mathrm{COO}$ - and the part of second central bridge $-\mathrm{N}=\mathrm{CH}$ - linking middle and third phenyl ring as well as left n-alkoxy terminal end group for the same homologue from series to series. Thus, they differ with respect to $-\mathrm{CH}=\mathrm{CH}$ - unit of a second central bridge in part, which contributes more or less to the total molecular rigidity and a tail end group $-\mathrm{OC}_{2} \mathrm{H}_{5}$ (series-1) which contributes more or less to the total molecular flexibility. Thus, variations in mesomorphic behaviors between the series under comparative study will depend upon the varying features of series-1and X. Following table-3 represent some mesomorphic properties of presently investigated series- 1 and a series $-X$ chosen for comparative purpose as under.

Table 3: Relative thermal stabilities in ${ }^{0} \mathrm{C}$

\begin{tabular}{|c|c|c|}
\hline Series & 1 & $\mathrm{X}$ \\
\hline Smectic-isotropic & 122.5 & 118.5 \\
Or & $\left(\mathrm{C}_{12}-\mathrm{C}_{18}\right)$ & $\left(\mathrm{C}_{12}-\mathrm{C}_{18}\right)$ \\
Smectic-nematic & & $\mathrm{C}_{12}$ \\
Commencement of & $\mathrm{C}_{12}$ & 224.77 \\
smectic phase & 270.7 & $\left(\mathrm{C}_{1}-\mathrm{C}_{18}\right)$ \\
\hline Nematic-isotropic & $\left(\mathrm{C}_{1}-\mathrm{C}_{18}\right)$ & $\mathrm{C}_{1}$ \\
commencement of & $\mathrm{C}_{1}$ & 73 to 111 \\
nematic phase & 111 to 194 & $\mathrm{C}_{18} \mathrm{C}_{1} \mathrm{C}_{6}$ \\
\hline Total mesophase length & $\mathrm{C}_{18} \mathrm{C}_{7}$ & \\
Range in ${ }^{0} \mathrm{C}$ & &
\end{tabular}

Looking to the above table,

- Homologous series 1 and $\mathrm{X}$ are smectogenic plus nematogenic.

- Smectogenic and/or nematogenic properties commences from $\mathrm{C}_{12}$ and $\mathrm{C}_{1}$ homologue for both series under comparative study.

- Smectogenic and nematogenic properties exhibited between $\left(\mathrm{C}_{12}-\mathrm{C}_{18}\right)$ and $\left(\mathrm{C}_{1}-\mathrm{C}_{18}\right)$ in case of both series 1 and $\mathrm{X}$ under comparison.

- Thermal stabilities for smectic and nematic as well as total mesophase length range are in decreasing order from series 1 to series $X$.

It is clear from above information that elimination of $-\mathrm{CH}=\mathrm{CH}$ - unit of second central bridge (series - 1) though reduces molecular rigidity and the simultaneously introduction of $-\mathrm{OC}_{2} \mathrm{H}_{5}$ polar group at the Para position of third phenyl ring increases molecular flexibility and the end to end attractions. Therefore thermal resistivity of series -1 for the same homologue from series to series against externally exposed thermal vibrations exceeds the corresponding values of series $-\mathrm{X}$. Thus, corresponding transition temperatures, thermal stability and total mesophase length of presently investigated homologous series - 1 are higher than a series $-\mathrm{X}$ chosen for comparison, otherwise commencement of smectic and nematic phase and the homologues between which mesophase exhibition take place and the type of mesophase shown resembled, are exactly same for series 1 and $\mathrm{X}$, their magnitudes differed by decreasing molecular rigidity by the elimination of - 
$\mathrm{CH}=\mathrm{CH}$ - unit of a central bridge and simultaneously increasing molecular flexibility by introducing $-\mathrm{OC}_{2} \mathrm{H}_{5}$ highly polar group as tail end group in series -1 . Thus, replacement or displacement or elimination of a polar functional group or groups or a part of group brings a great change in mesogenic properties or behaviours and the degree of mesomorphism.

\section{CONCLUSIONS}

- Homologous series of present investigation is partly smectogenic and fully nematogenic with high degree of mesomorphism and higher ordered melting type.

- Even a small change in molecular structure causes great change in molecular rigidity and or flexibility and consequently mesogenic properties and their magnitudes alters to a very great extent.

- Mesomorphism and degree of mesomorphism are very sensitive and susceptible to molecular structure.

- Present novel substances may be useful for the manufacture of LC device to be operated at high temperature as temperature indicator in heavy machinery.

- Present study very well supports the conclusions drawn earlier and raises the credibility to the early views.

\section{Acknowledgement}

Authors acknowledge thanks to the Department of Chemistry (DST-FIST Funded \& UGCSAP Sponsored), Saurashtra University, Rajkot, for research work. Authors are also thankful to Dr. A.V. Doshi, Ex. Principal M.V.M. Science and Home Science College Rajkot, for his valuable cooperation during present investigation as and when needed. Also thanks to the National Facility for Drug Discovery through New Chemical Entities (NCE's) for analysis of samples.

\section{References}

[1] F. Reinitzer, Monatsh 9,421 (1888)

[2] S. Narmura. Advance LCD technologies, Displays PP. 1, 22 (1) (2001).

[3] W.S. Kim, S. J. Elston and F.P. Raynes, Displays PP. 458-4636, 29 (2008).

[4] E. Hertz, B.Lavorel and O. Faucher, Optical imagine by molecular gas, Nature photon; PP. 783, 5 (2011).

[5] G. W. Gray and P. A. Winsor (Eds) Liquid Crystals and plastic crystals, chapter-6.2, The role of liquid crystal in life process by G. T. Stewart, Vol-1, PP. 308-326

[6] Prajkata P.Gaikwad, Maya T.Desai, 'Liquid crystalline phase and its Pharma application' international journal of Pharma Research and Review, PP. 40-52, (2013)

[7] G.W. Gray (1974) in; G. W. Gray and P. A. Winsor (eds) Liquid crystals and plastic crystals, chepter-4, Volume-1 PP-103-153, (2013).

[8] G. W. Gray, Molecular structures and properties of liquid crystals, Academic press, Landon, (1962).

[9] C. T. Imrie, Liq. Crystal dimmers. Struct. Bond 95 PP. 149-192, (1999).

[10] P. A. Henderson, O. Niemeyer, and C. T. Imrie, Mthylene-linked liquid crystal dimmers, Liq. Cryst.28 PP. 463-472, (2001).

[11] Hird. M, Toyne. K. J. and Gray. G. W, Day S.E and Mc. Donell D. G, Liq. Cryst. 15, PP. 123, (1993). 
[12] P. J. Collings and M. Hird (1997), Introduction of Liquid crystals chemistry and physics, Taylor and Francis Ltd. U.K. (1998).

[13] Marcos. M, Omenat. A, Serrano. J.L and Ezcurra. A Adv. Matter, 4, 285, (1992).

[14] Hird. M, Toyne. K.J, Gray G.W. Day S.E. Liq. Cryst. 14, PP. 741, (1993).

[15] D. Demus, 100 years of liquid crystal chemistry, mol.cryst. liq.crust. 165, PP. 45-84, (1988).

[16] D. Demus, Plenary lectures 100 years of liquid crystals chemistry, Thermotropic liquid crystals with conventional and unconventional molecular structures, liq.Cryst, 5. PP. 75-110, (1988).

[17] C. T Imrie and G. R,Luckhrust, "Liquid Dimers and oligomers in handbooks of liquid crystal, law molecular liquid crystals; Vol. 2B, D. Demus, J.W. Goodby,G.W. Graw, H. Spiess and V. Vill eds, Willey-VCH weinhe 1998, PP. 801-833.

[18] Doshi et at (1) D. M. Suthar and A.V. Doshi, Mol. Cryst. Liq. Cryst. Vol.575, PP. 76-83 (2) H. N. Chauhan and A. V. Doshi, Mol. Cryst. Vol. 570, PP. 92-100 (2013) (3) R. P. Chaudhari, M.L. Chauhan and A.V. Doshi, Vol. 575, PP. 88-95, (2013).

[19] D.M. Suthar, A. A. Doshi and A.V. Mole. Cryst. Liq. Cryst. Vol. 582, PP. 79-87, (2013).

[20] B. H. Patel, \& Doshi A.V, Vol. Cryst. Liq. Cryst., Vol-605, PP.42-51, (2015).

[21] B. H.Patel, \& Doshi A.V. Mol. Cryst. Liq. Cryst., Vol-607, PP. 78-86, (2015).

[22] B.Rajesh Marathe and Doshi A.V, Manuscript of a research paper entitled "Mesomorphism Dependences on Terminally Substituted End groups" accepted for publication to Mol. Crystal Liq. Crystal journal (Taylor and Francis) with its LCMH No.281, (2014).

[23] Aurangzeb Hasan 1,*, Asghar Abbas 2 and Muhammed Nadeem Akhtar, Molecule 16, 77897802 (2011).

[24] Y. Qian, H.-J. Zhang, H. Zhang, C. Xu, J. Zhao, and H.-L.Zhu, "Synthesis,molecular modeling, and biological evaluation of cinnamic acid metronidazole ester derivatives as novel anticancer agents," Bioorganic and Medicinal Chemistry, vol. 18, no. 14, pp. 4991-4996 (2010).

[25] I. Rukhsana, Kureshy,*[a] K. Jeya Prathap,[a] Santosh Agrawal,[a] Noor-ul H. Khan,[a] Sayed H. R. Abdi,[a] and Raksh V. Jasra [a] Eur. J. Org. Chem.,3118-3128 (2008).

[26] Qiang Wei, Lin Shi, Hui Cao, Liping Wang, Huai Yang* and Yangbin WangTaylor \&Francis Liquid Crystals, Vol. 35, No. 5, 581-585, (2008).

[27] U.C. Bhoya, N.N. Vyas and A.V. Dhosi, Mol. Cryst. Liq. Cryst., Vol. 552, PP-104-110, (2012).

[28] A.V. Doshi, U.C. Bhoya and J.J. Travadi, Mol. Cryst. Liq. Cryst. Vol.552, PP. 10-15; (2012).

[29] J. M. Lohar and A.V. Doshi, Science- Banglore, Vol-105, No-3, PP. 209-214, (1993).

[30] K. J. Ganatra and A.V. Doshi, Journal of Indian chem. Soc., Vol.77, PP. 322-325, (2000).

[31] D.T. Pidwani, G.N.Bhola and U.C. Bhoya Manuscript of a research paper entailed “ Mesomorphism Dependence on Molecular Flexibility at constant Rigidity" submitted to ILPCA Journal with dated on 15/04/2015. 